\title{
Implementation of Theory of Constraints To Improve Firm' Competitive Advantage: A Case Study in the Industrial Area of Bekasi, West Java Indonesia
}

\author{
Robertus Suraji, Istianingsih Sastrodiharjo \\ Informatics Program, Universitas Bhayangkara Jakarta Raya, Indonesia \\ Economics and Business faculty, Universitas Bhayangkara Jakarta Raya, Indonesia
}

\begin{abstract}
To maintain its survival, the company needs to maintain its competitive advantage and make it a unique strategy. This study was conducted to examine and determine whether there is an effect of using the Theory of constraints (TOC) on competitive advantage. Six indicators measured the TOC: Timely delivery to the customer, eliminating raw materials, controlling operational costs and reducing wastage, reducing cycle times and reducing inventory, Rapid response, and additional production capacity without additional investment. The competitive advantage is measured by five indicators: price, quality, delivery dependability, product innovation, and time to market.

This study uses all manufacturing companies that use the TOC method. The samples of the research were 100 manufacturing firms in Bekasi Industrial Area, West Java, Indonesia. Based on the Partial Least Square used in analyzing the data, the result showed that the TOC positively influences competitive advantage.
\end{abstract}

Keywords: Theory of constraints, Competitive advantage, Manufactur, Management Strategic

\section{Introduction}

The fourth industrial revolution is a reaction to changes in the business environment. For a company to be successful in the market, it is essential to respond effectively to the ever-changing customer demands. The point is that communication, automation, and computer technology, and the virtual world will meet and then be reflected in the physical world. Changes in market conditions are unavoidable condition. Companies also need to respond to changing technology and innovation to meet customer demands while maintaining costeffective optimization. Companies need to deal with these market conditions to be able to face financial difficulties and other financial problems. In the current era of globalization, increasingly fierce business competition has increased the rapid growth of technology and information systems, forcing companies to use new business management techniques (Baykasoglu \& Kaplanoglu, 2008). The company, through its management, must carry out the right strategy to compete with other companies to maintain the survival of the company. Having a competitive advantage is one way to win the business competition.

Competitive advantage is the ability of a company to be able to maintain its position over competitors. To maintain competitors' position, the company must have distinctive features that differentiate the company from competitors. This competitive advantage can be created in various ways, such as providing good quality, lower prices, satisfying customer service, et cetera.

In creating a competitive advantage, companies must provide services and products of high quality and at lower prices than those provided by competitors. Customers are usually more interested in choosing goods at affordable prices but with the same or even better quality than competitors. Price can be regarded as a factor that determines customer satisfaction (Bergman, 1995). Therefore, company managers must implement corporate strategies that can reduce and control production costs, reducing selling prices to create competitive selling prices. The selling price itself should not be too low to cover all costs incurred by the company and provide the desired profit, but also must not be too high to compete with its competitors. 
A company can set the selling price appropriately if the company can accurately calculate the production cost. For this reason, an accurate calculation of the production cost of a product is needed to determine a competitive selling price in the global market.

Every company will face limited resources and demand for each of its products. These limitations are called constraints. Theory of Constraints (TOC) is a strategic cost management philosophy developed by Goldratt in 1984. TOC states that constraints limit company performance. This Theory recognizes that companies' performance focuses managers' attention on the constraints or inefficiencies that hinder or slow down the production process. The main idea of this constraint theory is that the company organization will succeed according to the objectives set by maximizing the level of output (output) of the company as a whole.

Implementation of the TOC is the most optimal cost management strategy tool in achieving competitive advantage. Research by Cooper et al. (2007) can prove that the Theory of Constraints (TOC) can affect competitive advantage. The purpose of this study is to review and analyze whether the use of Theory of Constraints (TOC) can affect the competitive advantage of a company. The results of this study are expected to contribute to various parties, including a) Contribution of Theory: The results of this study are expected to provide a new view that the Theory of constraints (TOC) is essential to be applied as a tool of cost management systems. But more optimally. With the Theory of constraints (TOC), optimization of production costs both in the short and long term can be controlled and managed correctly to achieve the company's goal of competing in the market. b) In terms of scientific development, the results of this study are expected to be the basis for further research, that TOC is related to competitive advantage. 2) The results of this study are expected to provide a standard regarding good company management with the implementation of TOC as a cost management system tool to win a competitive advantage. c) Policy contribution: It is hoped that the government can make rules or policies that can help companies win competitive advantage, for example, relief or exemption from import duties on capital goods or machinery imported from abroad, to reduce constraints and reduce the cost of goods production, to increase market passion.

\section{Study Literature and Hypothesis Development Theory of constraints}

Gusnardi (2010), in his research, said that Goldratt developed the Theory of constraints to assist managers in increasing a company's profitability as a whole. This constraint theory focuses managers' attention on the constraints or inefficiencies that hinder or slow down the production process, giving the company a competitive advantage.

TOC was developed to help managers reduce cycle time and operating costs. (Blocher, 2011). Before using TOC, managers focused on increasing efficiency and speed through the entire production process rather than focusing only on obstacles or obstacles in the existing process. Unnecessary efficiency may result in an accumulation of goods in the supply process and divert attention and resources from the slowdown in cycle time. TOC coordinates the production process so that raw materials are available on time for the process, increases processing speed, and reduces or eliminates inventory.

This criticism of TOC is expressed in a study by Langfield-Smith et al. (2009). They argue that performance cannot be fully measured in the short term; therefore, to improve the company and maintain its future performance, the company must identify success factors that are strategic and related to performance measures-lacking in TOC. However, it has allowed firms to identify and remove barriers.

According to researchers, the link between TOC and competitive advantage is that with TOC, managers focus their attention on constraints or inefficiencies that hinder or slow down the production process to accelerate production, have better products, lower prices, and respond faster meeting customer needs. Thus, the company will have more competitive power than other companies because if the company is faster in responding to customer needs, the company will not be inferior to other companies. If the company is increasingly using the Theory of constraints, its competitive advantage will increase. Based on this description, this study proposes the first hypothesis as follows: 


\section{H1: The Theory of constraints has a positive effect on competitive advantage.}

\section{Research Method}

This type of research is hypothesis-deductive research, namely by testing hypotheses through theory validation or theory testing in specific applications. The type of investigation is correlational research, namely research aimed at finding the effect of applying the Theory of constraints on competitive advantage in manufacturing companies located in Bekasi and its surroundings. In Bekasi, many manufacturing companies use the Theory of constraints in their production cost management.

The type of data used in this research is quantitative data, measured by numbers and analyzed using statistics to answer questions or test specific research hypotheses and predict that a particular variable affects other variables.

\subsection{Population and research sample}

The population of this study is all manufacturing companies that use the Theory of constraints located in Bekasi, whose population is unknown. The sampling technique used is non-probability sampling, a sampling technique that does not provide equal opportunities for each element ber) of the population to be selected as members. In other words, not all of the population is selected as a sample (Sekaran, 2015).

The sampling technique used in this study was purposive sampling. Purposive sampling is a sampling technique used based on the considerations of the researcher in selecting the sample. The criteria in this sampling technique are managers who use the Theory of constraints and have served at least one year. Managers are chosen because the manager's position and above are considered to be the ones who know best what is going on in the company. In addition, managers are users of the information for decision-making. The consideration regarding the tenure must be at least one year because if it is less than one year, then it is assumed that the manager has not correctly understood the concept and the strengths and effects of the Theory of constraints in his company.

The number of samples in this study amounted to 100 manufacturing companies that use the Theory of constraints. To determine the minimum number of samples required, this study used the Lemeshow formula (1997). This requirement is because the population size is not known.

\subsection{Data collection technique}

The data source used in this study is to use primary data sources. Primary data refers to information obtained first-hand by researchers relating to variables of interest for the specific purpose of the study (Sekaran, 2015).

The research data was obtained through a survey. This survey was conducted through a questionnaire sent to the respondents. Questionnaires were sent via electronic mail (e-mail). Almost all respondents had been contacted by telephone. They were asked to fill out the questionnaire to enhance the respondents' responses and ensure that the respondents were included in the research criteria had been set. Respondents from this research are accounting managers of manufacturing companies who have served at least one year in manufacturing companies that use the Theory of constraints in their production cost management, which is located in Bekasi.

The period of this research is during the distribution of the questionnaires until their obtained have been collected. The data collection took place over approximately five months, from February 2019 to July 2019.

\subsection{Operational definition of a variable}

In his book, Sekaran (2015) states that a variable can differentiate or bring variation to Value. Values can be different at various times for the same object or person or at the same time. Operational definitions of the variables used in this study can be described as follows: 
The Theory of constraints is a theory that focuses managers' attention on constraints or waste that slows down the production process (Blocher et al., 2012). Theory of constraints recognizes that a decrease in inventory will reduce storage costs, thereby lowering operating expenses and increasing net income. TOC also states that the acceleration of production and a decrease in inventory will help produce competitive advantage by having better products, lower prices, and faster responses in meeting customer needs. The Theory of constraints variable is measured by six indicators (Goldratt, 1984), namely as follows :

Timely delivery to the customer (Timely delivery to the customer)

Eliminating out of raw materials

Control over operational costs and reduce waste

Reduce cycle times and reduce inventory (Reduce cycle times and reduce inventory)

Fast response (Rapid response)

Exposing additional production capacity without additional investment (Expose additional production capacity without additional investment)

This variable is measured by six questions with a 5 Likert scale from strongly disagree to agree strongly. The higher the score of this variable, the more influential the Theory of constraints on competitive advantage. The lower the score of this variable means that the Theory of constraints does not affect competitive advantage.

Competitive advantage

Li and Ragu-Nathan (2006) say that competitive advantage is defined as its ability to maintain its position from competitors. Maintaining the position allows the company to get a higher profit than competitors (Chen, Leu \& Chiou, 2006).

A company can gain a competitive advantage if the company has resources and capabilities superior to its competitors. Management must be able to use a more optimal strategy by utilizing resources and capabilities effectively.

Obtaining a competitive advantage will enable the company to achieve its corporate goals, namely business continuity (going concern); according to Li et al. (2006), the competitive advantage variable is measured by five indicators, namely: Price, Quality, Availability of delivery (Delivery dependability), Product innovation (Innovation). And Timeliness of launch to market (Time to market).

This variable is measured by five questions with a 5 Likert scale from strongly disagree, disagree, disagree, agree, to strongly agree. The higher the score of this variable, the greater the Theory of Constraints will affect competitive advantage. The lower the score of this variable means that the Theory of Constraints does not affect competitive advantage.

\subsection{Variable measurement}

Measurement (measurement) is the provision of property values of an object. The measurement scale used in this study to evaluate respondents' answers is the interval measurement scale. Including the interval scale because respondents are asked to sort the choices on the ranking according to their opinions which have the same interval or distance, and the ranking scale used is the Likert scale, with a 5 point scale from strongly disagree to agree strongly.

\subsection{Method of Analysis}

Data that has been obtained through questionnaires that have met the requirements will be further processed. The data received will be processed using Partial Least Square (PLS) with a calculation process assisted by the SmartPLS V.3.2.6 application program. This PLS method is used because it can explain whether or not 
Robertus Suraji et./al Implementation of Theory of Constraints To Improve Firm' Competitive Advantage: A Case Study in the Industrial Area of Bekasi, West Java Indonesia

there is a relationship between latent variables and confirming the Theory and does not require too many samples.

Multiple regression analysis model (Multiple Regression) proposed is whether competitive advantage is influenced by Theory of constraints, then the regression equation can be written as follows:

Where :

$\mathrm{KB}=$ Competitive Advantedge

$\alpha \mathbf{0}=$ Constant

$\beta \quad=$ Coefficient

TOC $=$ Theory of Constraints

$\varepsilon \quad=$ error

This study will examine the effect of the Theory of constraints on competitive advantage in manufacturing companies in Bekasi with an analysis model as shown in Figure 1

Figure 1. Hypothesis Analysis Model

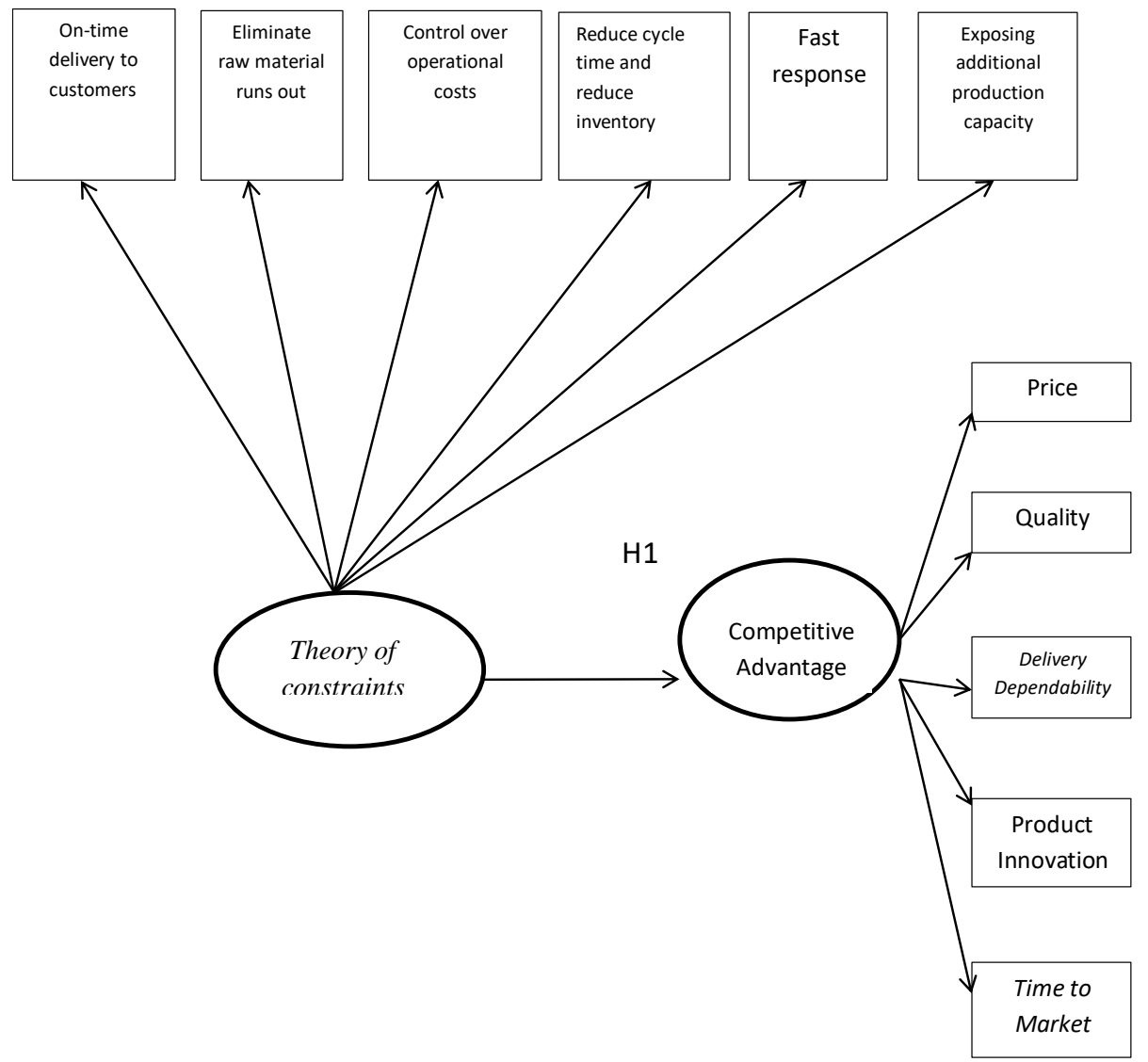

\subsection{Data analysis technique}

The stages of structural model analysis carried out in this study (Ghazali, 2014) are as follows:

1) Designing the Measurement Model (Outer model)

The outer model or measurement model defines how each indicator block relates to its latent variable. The design of the measurement model determines the indicator properties of each latent variable, whether reflective or formative, based on the operational definition of the variable. 
The outer model analysis is used to measure the Validity and Reliability of this research instrument. Outer model analysis can be seen from several indicators:

a) Convergent Validity

Convergent Validity is used to determine whether each estimated indicator validly measures the dimensions of the concept being measured. The individual reflexive measure is high if it correlates more than 0.70 with the construct to be measured. However, other opinions give tolerance for research in the early stages of developing a measurement scale for a loading value of 0.50 to 0.60 , which is considered sufficient (Chin 1998).

b) Composite Reliability

Cronbach Alpha reinforces the reliability test to measure the Reliability of the construct or latent variable; the Value must be above 0.60, which is considered reliable. Composite Reliability shows the degree that indicates common latent (unobserved), showing block indicators that measure internal consistency and construct indicators. The accepted limit value for the composite reliability level is 0.60 .

Average Variance Extracted

Average Variance Extracted is used to measure Validity, where the Value is 0.50

a) Discriminant Validity and Cross-loading

Discriminant Validity is an indicator measurement with its latent variables. It can be seen on the Cross Loading between the indicator and the construct.

Cross-loading measures the unidimensionality (single-dimensional or specific concept) of the latent variable.

1) Designing the Structural Model (Inner model)

Inner model or structural model describes the relationship between latent variables based on substantive Theory. The relationship between latent variables is based on the formulation of the problem or research hypothesis. Inner model or structural model analysis is done by looking at the percentage of Variance described, namely by looking at R2 for the latent dependent construct using the Stone Geisser Q-square test measure and also looking at the path size of the structural path coefficient. A T-statistical test evaluated the stability of this estimate, and the positive and negative effects were seen from the original sample $(\mathrm{O})$ obtained through the bootstrapping procedure.

a) Hypothesis Testing (Resampling Bootstrapping)

Hypothesis testing with PLS is done by resampling bootstrapping or jacking.

b) Coefficient of determination (R2)

This analysis is conducted to measure the ability of the research model in explaining the variation in the dependent variable. For example, the R2 value can go up or down.

\section{2) Finite Mixture Analysis}

Researchers generally treat data as if they were collected from a single population (Muthen, 1989). The assumption that the population is homogeneous is often unrealistic. Therefore several segments are made. The segmentation of respondents generally cannot be known beforehand, so it must be estimated from the existing data. By using the PLS Finite Mixture, it can detect heterogeneity in the inner path model relationship.

\section{TESTING ANALYSIS AND RESULTS}

\section{1. Descriptive Research Object}

The following is a descriptive response of respondents to the Theory of Constraints and Competitive Advantage variables at manufacturing companies in Bekasi.

Table 1. Descriptive Respondents' Answers on Variable Theory of constraints (X1)

\begin{tabular}{|l|c|c|}
\hline \multicolumn{1}{|c|}{ Indicator } & Mean & category \\
\hline Timely delivery to the customer & 4,54 & Very good \\
\hline Eliminating out of raw materials & 4,02 & Good \\
\hline Control operational costs and reduce wastage & 4,34 & Very good \\
\hline Reduce cycle times and reduce inventory & 3,68 & Good \\
\hline Rapid response & 4,51 & Very good \\
\hline Expose additional production capacity without & 3,83 & Good \\
\hline
\end{tabular}


Robertus Suraji et./al Implementation of Theory of Constraints To Improve Firm' Competitive Advantage: A Case Study in the Industrial Area of Bekasi, West Java Indonesia

\begin{tabular}{|c|c|c|}
\hline additional investment & & \\
\hline Total & $\mathbf{4 , 1 5}$ & Very good \\
\hline
\end{tabular}

Table 3. Descriptive of Respondents' Answers on Competitive Advantage (Y)

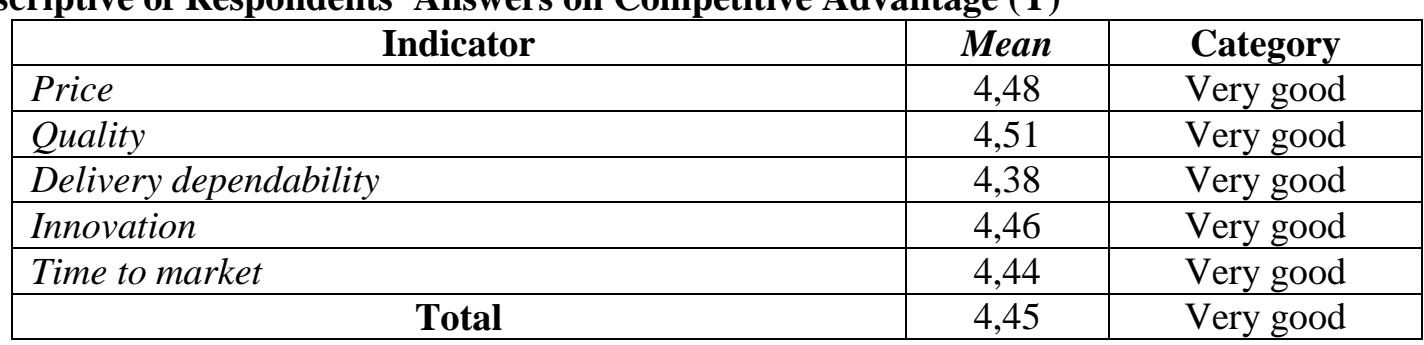

\subsection{Test Assumptions and Quality of Research Instruments}

Based on the results of data analysis using PLS, it was found that all indicators used had met the outer model test, which included convergent Validity, discriminant validity, and composite Reliability.

1) Assessing the Outer model (Measurement Model)

a) Convergent Validity

Convergent Validity of Measurement Model with reflexive indicators can be seen from the correlation between item/indicator scores and construct scores. Individual indicators are considered reliable if they have a correlation value above 0.70; however, at the scale development stage research, loading 0.50 to 0.60 is still acceptable.

The following results from convergent Validity for the Theory of constraints variable, and Competitive Advantage, for companies in Bekasi.

Table 4. Outer Loading Values

\begin{tabular}{|c|c|c|}
\hline & $\begin{array}{c}\text { Theory of } \\
\text { constraints }\end{array}$ & $\begin{array}{c}\text { Competitive } \\
\text { Advantage }\end{array}$ \\
\hline X1.1 & 0,935 & \\
\hline X1.2 & 0,913 & \\
\hline X1.3 & 0,930 & \\
\hline X1.4 & 0,798 & \\
\hline X1.5 & 0,906 & \\
\hline X1.6 & 0,818 & \\
\hline Y.1 & & 0,965 \\
\hline Y.2 & & 0,976 \\
\hline Y.3 & & 0,973 \\
\hline Y.4 & & 0,964 \\
\hline Y.5 & & 0,962 \\
\hline
\end{tabular}

Based on the table above, all indicators on the Theory of constraints and Competitive Advantage variables have an outer loading greater than 0.5 . This result means that the loading for each indicator is reliable.

b) Discriminant Validity

Discriminant validity of reflexive indicators can be seen in the Cross Loading between the indicator and its construct. Here are the results of Cross Loading:

Table 5. Cross Loading Value

\begin{tabular}{|c|c|c|}
\hline & $\begin{array}{c}\text { Theory of } \\
\text { constraints }\end{array}$ & $\begin{array}{c}\text { Competitive } \\
\text { Advantage }\end{array}$ \\
\hline $\mathrm{X} 1.1$ & $\mathbf{0 , 9 3 5}$ & 0,865 \\
\hline $\mathrm{X} 1.2$ & $\mathbf{0 , 9 1 3}$ & 0,775 \\
\hline $\mathrm{X} 1.3$ & $\mathbf{0 , 9 3 0}$ & 0,897 \\
\hline $\mathrm{X} 1.4$ & $\mathbf{0 , 7 9 8}$ & 0,653 \\
\hline $\mathrm{X} 1.5$ & $\mathbf{0 , 9 0 6}$ & 0,874 \\
\hline $\mathrm{X} 1.6$ & $\mathbf{0 , 8 1 8}$ & 0,685 \\
\hline $\mathrm{Y} .1$ & 0,893 & $\mathbf{0 , 9 6 5}$ \\
\hline
\end{tabular}


Robertus Suraji et./al Implementation of Theory of Constraints To Improve Firm' Competitive Advantage: A Case Study in the Industrial Area of Bekasi, West Java Indonesia

\begin{tabular}{|l|l|l|}
\hline Y.2 & 0,889 & $\mathbf{0 , 9 7 6}$ \\
\hline Y.3 & 0,851 & $\mathbf{0 , 9 7 3}$ \\
\hline Y.4 & 0,843 & $\mathbf{0 , 9 6 4}$ \\
\hline Y.5 & 0,893 & $\mathbf{0 , 9 6 2}$ \\
\hline
\end{tabular}

From table 5 above, it can be seen that all indicators with cross-loading values show good discriminant validity because of the correlation value of the indicator against the construct. The number is higher than the correlation value of the indicator with other constructs (the loading factor is in bold). The correlation of the TOC construct with its indicators is higher than the correlation of the TOC construct to other indicators. The correlation of the construct of competitive advantage with its indicator is higher than the correlation of the construct of competitive advantage against other indicators.

This number shows that the latent construct predicts indicators in their block better than indicators in other blocks.

c) Average Variance Extracted.

Another test is to assess the validity of the construct. This step is looking at the AVE value. A good model has required if the AVE of each construct is more significant than 0.50 .

Table 6. Average Variance Extracted.

\begin{tabular}{|c|c|}
\hline & AVE \\
\hline Theory of Constraints & 0,783 \\
\hline Competitive Advantage & 0,937 \\
\hline
\end{tabular}

The AVE output results show that the AVE value is suitable for all constructs. For example, the Value of the Theory of constraints constructs and Competitive Advantage has an AVE value greater than 0.50.

d) Composite Reliability and Cronbach Alpha

In addition to constructing validity tests, construct reliability tests were also carried out - these steps were measured by two criteria, namely Composite Reliability and Cronbach Alpha. Thus two numbers are from the indicator block that measures constructs.

The construct is declared reliable if the Composite Reliability value and the Cronbach Alpha value are above 0.70.

The following is the output:

Table 7. Composite Reliability

\begin{tabular}{|c|c|}
\hline & Composite Reliability \\
\hline $\begin{array}{c}\text { Theory of } \\
\text { Constraints }\end{array}$ & 0,956 \\
\hline $\begin{array}{c}\text { Competitive } \\
\text { Advantage }\end{array}$ & 0,987 \\
\hline
\end{tabular}

Table 8. Cronbach Alpha

\begin{tabular}{|c|c|}
\hline & Cronbach Alpha \\
\hline $\begin{array}{c}\text { Theory of } \\
\text { Constraints }\end{array}$ & 0,944 \\
\hline $\begin{array}{c}\text { Competitive } \\
\text { Advantage }\end{array}$ & 0,983 \\
\hline
\end{tabular}

The output results of Composite Reliability and Cronbach Alpha both for the Theory of constraints constructs and Competitive Advantage are all above 0.70. So it can be concluded that the construct has good Reliability.

2) Assessing the Inner Model or Structural Model

Testing the structural model is carried out by looking at the R-Square Value, which is the goodness-fit test of the model. Here are the results of the R-Square:

Table 9. R-Square

\begin{tabular}{|c|c|}
\hline & R-Square \\
\hline Competitive Advantage & 0,852 \\
\hline
\end{tabular}

The Theory of Constraints influence model on Competitive Advantage provides an R-Square value of 0.852. This number means that the variability of the Competitive Advantage construct, which the Theory of Constraints can 
explain, is $85.2 \%$. At the same time, $14.8 \%$ is explained by other variables outside those studied in this study. This number means that the regression model in this study has a good level of best fit.

3) Finite Mixture Analysis (FIMIX)

Fix-PLS analysis is used to detect whether the analyzed data has heterogeneity. There is the segmentation of respondents. For this reason, the analysis is carried out by dividing the data into two segments.

To determine the best number of segments, we must compare values. The primary purpose of this analysis is to capture the heterogeneity of data grouping in the inner path. The Normed Entropy (EN) statistic is a criterion for analyzing class-specific results from FIMIX PLS. The amount of EN value ranges from 0 to 1 . The increase in the EN value shows that the quality of segmentation class separation is getting better. EN values above 0.50 indicate good segmentation. Following are the results of the Fimix PLS analysis.

Table 10. Fit Indices

\begin{tabular}{|c|c|c|c|}
\hline & 2 Segment & 3 Segment & 4 Segment \\
\hline EN & 0,713 & 0,671 & 0,640 \\
\hline
\end{tabular}

Based on the criteria in the table above, two segments are the best segmentation because they provide the highest EN value, which is 0.713 .

The following are the results of the SmartPLS FIMIX analysis with two segments.

Table 11. FIMIX-PLS Segmentation Results

\begin{tabular}{|l|c|c|}
\hline & SEGMENT 1 & SEGMENT 2 \\
\hline R2 (Competitive Advantage) & 0,843 & 0,996 \\
\hline Segment Sizes & $\mathbf{0 , 5 7 7}$ & 0,423 \\
\hline TOC - $\rightarrow$ Competitive Advantage & 0,433 & 0,015 \\
\hline
\end{tabular}

From the table of the results of Fimix PLS Segmentation for two latent variable segments, it can be seen that the large segment (Sigmen $1=$ Size 0.577 ) gives a relatively high $\mathrm{R} 2$ value of 0.843 . These variables also influence the TOC variable is 0.433 , higher than segment 2 , which is only 0.015 . This situation can be interpreted that different respondent segments will produce different results.

\subsection{Hypothesis test}

The next test is to see the significance of the effect of Theory of Constraints on Competitive Advantage, which can be explained by looking at the parameter coefficient value and the T-statistical significance value.

The following is the output:

The following shows the output results of the regression coefficient parameters.

Table 12. Path Coefficients (Mean, STDEV, T-Values)

\begin{tabular}{|l|c|c|c|c|c|}
\hline & $\begin{array}{c}\text { Original } \\
\text { Sample } \\
(\mathrm{O})\end{array}$ & $\begin{array}{c}\text { Sample } \\
\text { Mean } \\
(\mathrm{M})\end{array}$ & $\begin{array}{c}\text { Standard } \\
\text { Deviation } \\
\text { (STDEV) }\end{array}$ & $\begin{array}{c}\text { Standard } \\
\text { Error } \\
\text { (STERR) }\end{array}$ & $\begin{array}{c}\text { T Statistics } \\
\text { (O/STERR) }\end{array}$ \\
\hline $\begin{array}{l}\text { TOC } \rightarrow \\
\text { Competitive } \\
\text { Advantage }\end{array}$ & 0,382 & 0,380 & 0,169 & 0,168 & 2,262 \\
\hline
\end{tabular}

From the table above, it can be seen that the test results show the parameter coefficient of 0.382 . This number means a positive effect of Theory of Constraints on competitive advantage and is significant at 0.05. ( $\mathrm{T}$ count $>\mathrm{T}$ table 1.96). This result means that as hypothesized in $\mathrm{H} 1$, it is proven that the Theory of Constraints has a positive effect on competitive advantage.

\subsection{Discussion}


Every company owner wants his company to be able to control the existing market and be able to maintain the sustainability of his company (Going Concern). Therefore, company owners are willing to pay or hire other people (agents) who can provide their services to provide a strategy to achieve success in competition in the market. Agents, in this case as company management, must also be able to account for the results of their work by choosing and using the right management strategy. Agency theory, in this case, underlies the relationship between company owners and managers in achieving company goals.

Managers must choose the most optimal cost management strategy for competitive advantage for the short term and the long term. The results of this study are:

1) Theory of Constraints has a positive effect on competitive advantage; it can be seen from the table above that the test results show the magnitude of the parameter coefficient of 0.382 . These results are consistent with research by Atwater (1997) that the Theory of constraints can help managers increase the contribution margin to increase competitive advantage.

By focusing attention on constraints or inefficiencies that hinder or slow down, the production process can give a company a competitive advantage.

\section{Conclusions, Implications, Limitations, And Suggestions}

\subsection{Conclusions}

This research is motivated by various previous studies on analyzing the influence of the Theory of Constraints on competitive advantage. The purpose of this study was to review the extent to which the Theory of Constraints affects competitive advantage. This research was conducted on a manufacturing company located in Bekasi, with primary data obtained through a questionnaire of 100 respondents.

Based on the results of hypothesis testing in the previous chapter, it can be concluded that there is a positive influence between Theory of Constraints on competitive advantage where the application of Theory of Constraints in manufacturing companies in Bekasi. By implementing the Theory of Constraints as a tool of strategic cost management, the company will achieve a more optimal competitive advantage. The results of this study support the research of Atwater \& Gagne (1997), Cooper \& Parzen (2007), Kee (1995), and Vergauwen \& Kerekhoffs (2005).

\subsection{Implications}

This study confirms that the Theory of Constraints affects competitive advantage. The contribution of this research theory is expected to provide a new view. The Theory of constraints (TOC) plays an essential role in optimizing shortterm and long-term production costs. The two costs type can be controlled and managed to achieve the company's goal of competing in the market.

For practical contributions, this research will be the rationale for further research. TOC is related to competitive advantage and can provide a standard regarding good corporate management by implementing TOC as a cost management system tool to win competitive advantage.

\subsection{Limitations and Suggestions}

This study has several limitations that may affect the research results to be achieved. These limitations are:

1) The inherent limitations of the data obtained through questionnaires are due to differences in the perceptions of researchers and research respondents. However, subsequent research can deepen the analysis using interviews with informants from the President Director and other Directors within the company who understand the implementation of TOC.

2) In the Theory of Constraints indicator, there is an indicator with the smallest mean, reducing cycle times and reducing inventory. Therefore the company must optimize inventory management.

3) Manufacturing companies should use the Theory of Constraints in their production process because it will increase their competitive advantage in the market.

4) Include other variables that can support the company's competitive advantage, such as intellectual capital management and good corporate governance.

\section{Bibliography}

1. Atkinson, A. A., Kaplan, R. S., Matsumura, E. M., \& Young, S. M. (2012). Management AccountingInformation for Decision Making and Strategy Execution $\left(6^{\text {th }}\right.$ ed). New Jersey: Pearson.

2. Atwater, B., \& Gagne, M.L. (1997). The Theory of Constraint Versus Contribution Margin Analysis for Product Mix Decision. Journal of Cost Management. The University of South Florida. 
Robertus Suraji et./al Implementation of Theory of Constraints To Improve Firm' Competitive Advantage: A Case Study in the Industrial Area of Bekasi, West Java Indonesia

3. Bergman, R. L. (1995). Integrating Marketing, Operating, and Purchasing to Create Value. Omega 23(2), 159172.

4. Bogdanoiu, C. (2009). Activity-Based Cost From The Perspective of Competitive Advantage. Journal of Applied Economic Sciences, Vol. IV, Issue 1 (7)/Spring.

5. Bushong, J. G., \& Talbott, J. C. (1999). An Application of The Theory of Constraints. The CPA Journal.

6. Blocher, E. J., Stout, D. E., \& Cokins, G. (2011). Manajemen Biaya: Penekanan Strategis ( $5^{\text {th }}$ ed). Jakarta: Salemba Empat.

7. Cagwin, D., \& Bouwman, J. M. (2002). The Association Between Activity-Based Costing and Improvement in Financial Performance. Journal of Management Accounting Research, 13, 1-39.

8. Carter, W. K., Usry, M. F., \& Hammer, L. H. (2008). Akuntansi Biaya-Cost Accounting (14 ${ }^{\text {th }}$ ed). Jakarta: Salemba Empat.

9. Chen, Y. C., Leu, D. J., \& Chiou, H. C. (2006). The Impact of E-Supply Chain Capability on Competitive Advantage and Organizational Performance. International Journal of Electronic Business Management, 4 (5), 419-427.

10. Chin, W. W. (1998). The Partial Least Squares Approach for Structural Equation Modeling. In Marcoulides, GA. (ed) Modern Method for Business Research. New Jersey: Lawrence Erlbaum Associates.

11. Cooper, R., Bray, D., \& Parzen, M. (2007). Who Wins in a Dynamic World: Theory of Constraints vs. Activity-Based Costing. Journal of Costing Management.

12. Garrison, R. H., Noreen, E. W., \& Brewer, P. C. (2013). Akuntansi Manajerial (14 $\left.{ }^{\text {th }} e d\right)$. Jakarta: Salemba Empat.

13. Ghozali, I. (2014). Partial Least Squares: Konsep Teknik dan Aplikasi Menggunakan Program SmartPLS 3.0 untuk Penelitian Empiris. Semarang: Badan Penerbit Universitas Diponegoro.

14. Ghozali, I. (2014). Struktural Equation Modeling: Metode Alternatif dengan Partial Least Squares (PLS) (4 ${ }^{\text {th }}$ ed). Semarang: Badan Penerbit Universitas Diponegoro.

15. Goldratt, E. M., \& Cox, J. (1992). The Goal: A Process of Ongoing Improvement, $\left(2^{\text {nd }} e d\right)$, New York: North River Press.

16. Goldratt, E. M., \& Fox, R. (1989). The Importance of a Systems Constraints. The Theory of Constraints Journal 1(February):5-7.

17. Gordon, L. A., \& Silvester, K. J. (1999). Stock Market Reactions to Activity-Based Costing Adoptions. Journal of Accounting \& Public Policy, Vol. 18 (3), Autumn, pp. 229-251.

18. Hansen, D. R., \& Mowen, M. M. (2009). Managerial Accounting-Akuntansi Manajerial ( $8^{\text {th }}$ ed). Jakarta: Salemba Empat.

19. Hilton, R. W., Michael, M. W., \& Frank, S. H. (2003). Cost Management- Strategies for Business Decisions. New York: The McGraw Hill.

20. Horngren, C.T., Datar, S. M., Foster, G., Rajan, M., \& Ittner, C. (2015). Cost Accounting: A Managerial Emphasis $\left(15^{\text {th }} \mathrm{ed}\right)$. United Kingdom: Pearson Education International.

21. Jensen \& Meckling (1976). Theory of the Firm: Managerial Behavior, Agency Cost and Ownership Structure. Journal of Financial Economics.

22. Kaplan, R. S., \& Anderson, S. R. (2003). Time-Driven Activity-Based Costing. Journal of Management Accounting Research.

23. Khataie, A. H. (2011). Activity-Based Costing in Supply Chain Cost Management Decision Support Systems. Thesis in The Department of Mechanical and Industrial Engineering at Concordia University. Canada.

24. Kee, R. (1995). Integrating Activity-Based Costing with the Theory of Constraints to Enhance ProductionRelated Decision Making. American Accounting Association Accounting Horizons Vol.9 No.4. 48-61.

25. Langfield-Smith, K., Thorne, H., \& Hilton, R. (2009). Management Accounting Information for Creating and Managing Value $\left(5^{\text {th }}\right.$ ed). Sydney: McGraw-Hill.

26. Lemeshow, S., \& David, W. H. Jr. (1997). Besar Sampel Dalam Penelitian Kesehatan. Yogyakarta: Gadjahmada University Press. 
Robertus Suraji et./al Implementation of Theory of Constraints To Improve Firm' Competitive Advantage: A Case Study in the Industrial Area of Bekasi, West Java Indonesia

27. Istianingsih and Suraji. 2020. The Impact of Competitive Strategy and Intellectual Capital on SMEs Performance. Jurnal Manajemen/Volume XXIV, No. 03, October 2020: 427-442 DOI: http://dx.doi.org/10.24912/jm.v24i3.677

28. Istianingsih and Suraji. 2020. Kekuatan Spiritualitas Dalam Entrepreneurship. CV. Pena Persada Press.

29. Suraji, Robertus and Istianingsih. 2021. Entrepreneurship (Sistem Ekonomi Pasca-Kapitalis). Penerbit Ykpn Yogyakarta.

30. Istianingsih, and Trireksani, Terri and Manurung, Daniel T. H. (2020) The Impact of Corporate Social Responsibility Disclosure on the Future Earnings Response Coefficient (ASEAN Banking Analysis). ANUVA, 4 (2). pp. 271-286. ISSN 2598-3040

31. Li, S., Ragu-Nathan, B., Ragu-Nathan, T. S. \& Rao, S.S. (2006). The Impact of Supply Chain Management Practices on Competitive Advantage and Organizational Performance. The International Journal of Management Science, 107-124.

32. Muthen, Bengt O. (1989). Latent Variable Modeling in Heterogeneous Population. Psychometrika, 54. 557585.

33. Mulyadi. (2007). Sistem Perencanaan dan Pengendalian Manajemen: Sistem Pelipatganda Kinerja Perusahaan $\left(3^{\text {th }} e d\right)$. Jakarta: Salemba Empat.

34. Porter, M. E. (1985). Competitive Advantage: Creating and Sustaining Superior Performance. New York: The Free Press.

35. Rahman, A. (2016). Investor Hengkang, Buruh Tekangkang. Diakses pada tanggal 04 Februari 2016, dari World Wide Web: http://www.kompasiana.com/asmarirahman/investor-hengkang-buruhtekangkang_56b30898c723bd8506e0fdcc.

36. Sekaran, U. (2012). Research Methods for Business: A Skill Building Approach (6th ed). New York: John Willey and Sons.

37. Shank, J. K., \& Govindarajan, V. (1993). Strategic Cost Management- The New Tool for Competitive Advantage. New York: The Free Press.

38. Segovia, J. J., \& Khataie, A. H. (2011). The Financial Performance Effects of Activity-Based Costing/Management in The Telecommunications Industry. Society of Interdisciplinary Business Research, 16.

39. Sheu, C., Chen, M. H., \& Kovar, S. (2003). Integrating ABC and TOC for Better Manufacturing Decision Making, Integrated Manufacturing Systems $\quad$ Vol. $14 \quad$ Iss:5, pp.433-441. http://dx.doi.org/10.1108/09576060310477834

40. Shields, M. D. (1995). An Empirical Analysis of Firm's Implementation Experiences with Activity-Based Costing: Journal Management Accounting Research, Fall, 148-166.

41. Sumarsid. (2011). Pendekatan Metode Activity-Based Costing Pada Perencanaan Harga Pokok Produksi untuk Memperoleh Keunggulan Bersaing. Jurnal Ilmiah Ekonomi Manajemen dan Kewirausahaan “Optimal”, 5 (1),71-90.

42. Sugiyono. (2012). Metode Penelitian Bisnis. Bandung: Alfabeta.

43. Tracey, M., Vonderembse, M. A. \& Lim, J. S. (1999). Manufacturing Technology and Strategy FormulationKey to Enhancing Competitiveness and Improving Performance. Journal of Operations Management 17, 411428.

44. Vergauwen, P. G. M. C. \& Kerekhoffs, C. J. M. C. (2005). Using Activity-Based Costing And Theory of Constraints to Enhance Decision Making at Duographics B.V: A Case Study. Journal of Management Accounting Research. 